\title{
41. STRATIGRAPHY AND SEDIMENT ACCUMULATION PATTERNS OF THE UPPER CENOZOIC PELAGIC CARBONATE CAPS OF GUYOTS IN THE NORTHWESTERN PACIFIC OCEAN ${ }^{1}$
}

\author{
David K. Watkins, ${ }^{2}$ Paul N. Pearson, ${ }^{3}$ Elisabetta Erba, ${ }^{4}$ Frank R. Rack,,${ }^{5}$ Isabella Premoli Silva, ${ }^{4}$ \\ Horst W. Bohrmann, ${ }^{6}$ Julianna Fenner, ${ }^{7}$ and Peter R.N. Hobbs ${ }^{8}$
}

\begin{abstract}
Many of the guyots of the Northwestern Pacific Ocean are capped by sequences of uncemented pelagic carbonate. Examination of three of these pelagic caps from Limalok, Lo-En, and Wodejebato guyots in the Marshall Islands indicates that sediment accumulation throughout the late Paleogene and late Cenozoic was characterized by episodes of deposition during the earliest Miocene, late early to early middle Miocene, late middle Miocene, mid-Pliocene, and Quaternary, separated by periods of little or no accumulation. The Miocene record consists of extensively winnowed foraminifer oozes, which suggest relatively energetic currents in the intermediate waters. The Pliocene and Quaternary sequences contain finer grained nannofossil oozes, suggesting lower intermediate-water current velocities. Comparison with guyots from more northern locations indicates a highly predictable relationship between modern latitude and pelagic cap thickness, with thickness decreasing toward the north. Stratigraphic and seismic reflection evidence suggests that erosion is the major factor contributing to the diminution and eventual destruction of the pelagic caps as they are rafted northward by the motion of the Pacific Plate.
\end{abstract}

\section{INTRODUCTION}

Ocean Drilling Program (ODP) Leg 144 recovered Oligocene through Pleistocene pelagic carbonate oozes from four guyots in the northwestern Pacific Ocean. These guyots share many characteristics with other guyots in the world's oceans. They consist of a volcanic edifice whose summit is often flat-topped owing to subaerial or submarine erosion. Many have a shallow-water carbonate sequence atop the summit plateau. This formed early in its subsidence history, when the guyot was near sea level. Finally, many are capped by a sequence of pelagic sediments (referred to in this paper as the "pelagic cap"), which accumulated as the guyot subsided into the pelagic realm. Limalok and Wodejebato guyots possess all three elements. Lo-En Guyot lacks the carbonate platform complex in the vicinity where Site 872 was drilled by Leg 144. MIT Guyot lacks a true pelagic cap, as pelagic carbonate is present only in sheltered depressions on the summit plateau.

Data for this paper are derived from examinations of several fossil groups, including planktonic foraminifers (Pearson, this volume), calcareous nannofossils (Watkins et al., this volume; D.K. Watkins and E. Erba, unpubl. data), and diatoms (Fenner, this volume). Geotechnical and eolian data are derived from Rack et al. (data reports

\footnotetext{
'Haggerty, J.A., Premoli Silva, I., Rack, F., and McNutt, M.K. (Eds.), 1995. Proc ODP, Sci. Results, 144: College Station, TX (Ocean Drilling Program).

2 Department of Geology. University of Nebraska, Lincoln, Nebraska 68588-0340, U.S.A.

${ }^{3}$ Department of Earth Sciences, University of Cambridge, Downing Street, Cambridge, CB2 3EQ. United Kingdom. (Present address: Department of Geology, Wills Memorial Building, University of Bristol, Queens Road, Bristol BS8 IRJ, United Kingdom.)

${ }^{4}$ Dipartimento di Scienze della Terra, Università degli Studi di Milano, Via L. Mangiagalli 34, 1-20133 Milano, Italy.

${ }_{5}$ Ocean Mapping Group, Department of Geodesy and Geomatics Engineering, University of New Brunswick, Fredericton, New Brunswick E3B 5A3, Canada.

${ }^{6}$ GEOMAR, Forschungszentrum für Marine Geowissenschaften, Waitzstrasse 67 , D-24105 Kiel, Federal Republic of Germany.

${ }^{7}$ Bundesanstalt für Geowissenschaften und Rohstoffe, Postfach 510153, D-300 Hannover 51. Federal Republic of Germany.

${ }^{8}$ British Geological Survey, Engineering Geology and Geophysics Group, Keyworth, Nottingham NG12 5GG, United Kingdom.
}

and synthesis, this volume) and Premoli Silva, Haggerty, Rack, et al. (1993). The time scale used is from Cande and Kent (1992).

Here we synthesize these data to derive a coherent history for the development of the Leg 144 pelagic caps. These data are then combined with information from other guyots in an attempt to explain the distribution and late Cenozoic history of pelagic caps on guyots in the northwestern Pacific.

\section{LIMALOK GUYOT (SITE 871)}

Site 871 is located at $5^{\circ} 33.43^{\prime} \mathrm{N}, 172^{\circ} 20.66^{\prime} \mathrm{E}$, near the summit of Limalok Guyot in $1255 \mathrm{~m}$ water depth. Limalok Guyot (formerly Harrie Guyot) is in the Ratak Chain of the southern Marshall Islands (see site map preceding the title page). Limalok Guyot occupies the same volcanic pedestal as Mili Atoll. The shallow-water carbonate complex on Mili Atoll continues to thrive. However, shallow-water carbonate deposition on Limalok Guyot ceased during the middle Eocene (Nicora et al, this volume). Platform drowning was followed by deposition of manganese-encrusted hardgrounds during the middle Eocene through (?)Oligocene (Watkins et al., this volume). Deposition of the carbonate pelagic cap began during the early early Miocene.

Holes $871 \mathrm{~A}$ and $871 \mathrm{~B}$ were drilled to recover the pelagic cap on Limalok. Hole $871 \mathrm{~A}$ cored $151.9 \mathrm{~m}$ with a recovery of approximately $83 \%$. Hole $871 \mathrm{~B}$ had a similar penetration $(152.4 \mathrm{~m})$ but significantly lower $(68.2 \%)$ recovery. Given this comparative recovery, paleontological investigations were concentrated on the more complete record from Hole $871 \mathrm{~A}$.

The pelagic carbonate sequence in Hole $871 \mathrm{~A}$ consists of a single lithologic unit divisible into two subunits (IA and IB) based on its lithologic and geotechnical properties. Subunit IA (Core 144-871A$1 \mathrm{H}$ to Section 144-871A-3H-CC; 0-26.6 m below seafloor [mbsf]) consists of a light gray (5Y 6/2) nannofossil foraminifer ooze. Calcium carbonate content is generally between $94 \%$ and $98 \%$ of the ooze. This subunit is characterized by generally lower porosity $(70 \%-$ $75 \%)$, lower water content ( $40 \%-50 \%)$, and higher dry bulk density $\left(0.75-0.9 \mathrm{~g} / \mathrm{cm}^{3}\right)$ than the underlying Subunit IB. The eolian component $(<63 \mu \mathrm{m})$ makes up approximately $0.2 \%-0.75 \%$ of the dry sediment. Subunit IB (Cores 144-871A-4H to $-15 \mathrm{H}$; 26.5-139.5 mbsf) 
consists of white foraminifer ooze. This subunit is dominated by planktonic foraminifers that generally make up more than $90 \%$ of the sediment. The medium sand texture of the sediment and its homogenous nature indicates that it was extensively winnowed during its deposition. The sediment in this subunit was very soupy when recovered from the hole, and considerable mixing occurred within the core liner. The winnowed nature of the sediment and its waterlogged condition are reflected in the higher porosity $(75 \%-82 \%)$, lower dry bulk density $\left(0.4-0.6 \mathrm{~g} / \mathrm{cm}^{3}\right)$, and higher water content $(40 \%-50 \%)$ in Subunit IB as compared with Subunit IA.

Biostratigraphic analysis based on combined planktonic foraminifer and calcareous nannofossil age determinations indicates the presence of five intervals of temporally contiguous sediment separated by four disconformities (Fig. 1). Three of these sediment units occur within lithologic Subunit IA.

The youngest interval includes sediment from Core $144-871 \mathrm{~A}-1 \mathrm{H}$ through Sample 144-871A-3H-2, 60-61 cm (0-19.1 mbsf). This interval is contained within planktonic foraminifer Zone N22. Calcareous nannofossil biostratigraphy indicates a relatively complete sequence of sediments. All seven of Gartner's (1977) Pleistocene zones are represented. In addition, the base of this sequence contains nannofossil assemblages of Subzone CN12d of latest Pliocene age. The last appearance datum (LAD) of Globigerinoides fistulosus and the first appearance datum (FAD) of Gephyrocapsa oceanica, criteria for delimiting the Pliocene/Pleistocene boundary for foraminifers and nannofossils, respectively, both occur at the base of Core 144-871 A $2 \mathrm{H}$. The overall rate of sediment accumulation for this interval is approximately $10 \mathrm{~m} / \mathrm{m} . \mathrm{y}$. Examination of the sediment accumulation rates for individual nannofossil zones indicates that most are within the range of $8-14 \mathrm{~m} / \mathrm{m} . \mathrm{y}$. The sediment accumulation rate within the Emiliania huxleyi Zone is significantly higher, with a value of $18 \mathrm{~m} /$ m.y. This zone corresponds to the highest levels of eolian dust in Subunit IA (Fig. 1). This uppermost Pliocene and Pleistocene interval is separated from the underlying sediment interval by a disconformity with a minimum hiatus of approximately $0.7 \mathrm{~m} . \mathrm{y}$.

The underlying interval of nannofossil foraminifer ooze (Samples 144-871 A-3H-2, 80-81 cm, through -3H-3, 135-136 cm; 19.3-21.4 mbsf) is entirely contained within the mid-Pliocene Discoaster tamalis Subzone (CN12a). This contains the upper part of Zone N20 and the lower part of Zone N21. The minimum sediment accumulation rate for this interval is approximately $3 \mathrm{~m} / \mathrm{m}$.y. This mid-Pliocene sediment is separated from the underlying upper Miocene ooze by a disconformity with a hiatus of approximately 2.1 m.y.

The lowest biostratigraphic interval in lithologic Subunit IA consists of $3.6 \mathrm{~m}$ of upper Miocene nannofossil foraminifer ooze (Samples 144-871 A-3H-4, 60-61 cm, through -3H-CC; 22.1-25.7 mbsf). This interval is characterized by generally poorly preserved nannofossil assemblages that belong to Subzone CN9b. Planktonic foraminifer preservation is significantly better in this interval and allows division into two subzones (N17a and N17b). Reworked microfossils are prominent near the base of this interval. Foraminifer assemblages in Sections 144-871A-3H-5 through -3H-CC contain reworked middle Miocene (Fohsella fohsi group), lower Miocene (Globigerinoides bisphericus and Praeorbulina spp.), and Oligocene species (Paragloborotalia opima and Catapsydrax spp.). Calcareous nannofossil assemblages from Sections 144-871 A-3H-6 and -3H-CC contain numerous Oligocene species, including Dictyococcites bisectus and $C y$ clicargolithus abisectus. The middle Miocene planktonic foraminifers possibly were derived from the stratigraphically adjacent Subunit IB. The presence of the lower Miocene and Oligocene microfossils indicates that exhumation and mobilization of significantly older sediments was occurring on the guyot summit during the late Miocene. Despite the influx of reworked microfossils, the sediment accumulation rate for this interval is relatively low $(<4 \mathrm{~m} / \mathrm{m} . \mathrm{y}$. $)$. This interval (the base of Subunit IA) is separated from the top of Subunit IB by a disconformity with a hiatus of at least 3.3 m.y.
The winnowed, waterlogged nature of the foraminifer oozes in Subunit IB significantly affected the biostratigraphic integrity of the recovered sediment. Calcareous nannofossils are generally rare and poorly preserved, suggesting that most were removed or at least remobilized several times during deposition. In addition, the high water content and medium sand texture of the sediment often allowed suspended nannofossils to move throughout much of the length of the core before its curation. As a result, reworking and mixed assemblages are common throughout most of Subunit IB. Given these problems, the planktonic foraminifer age determinations for this subunit are thought to be more accurate in general.

Two biostratigraphic intervals are recognizable in Subunit IB. The upper interval (Core 144-871A-4H through Sample 144-871A$6 \mathrm{H}-6,60-61 \mathrm{~cm} ; 25.7-54.2 \mathrm{mbsf}$ ) contains planktonic foraminifer assemblages of middle Miocene Zone N12. These sediments probably contributed the Fohsella fohsi group specimens reworked into the base of Subunit IA. Calcareous nannofossils in this interval contain poorly preserved assemblages attributed to Zone CN5. Preservation in the base of this interval is too poor to allow subzonal assignment. Better preserved assemblages in the upper part of the interval contain identifiable Discoaster kugleri, indicating Subzone CN5b. This subzone is, in part, correlative with planktonic foraminifer Zone N12. Sediment accumulation in this interval was more rapid (approximately $17 \mathrm{~m} / \mathrm{m} . \mathrm{y}$.) than that in Subunit IA. This interval is separated from the underlying one by a disconformity with a hiatus of at least 1.3 m.y.

The lower interval (Section 144-871A-6H-CC through Core 144$871 \mathrm{~A}-15 \mathrm{H} ; 55.0-139.2 \mathrm{mbsf})$ in Subunit IB consists of a relatively continuous sequence of lower to lower middle Miocene foraminifer ooze (Fig. 1). Calcareous nannofossil reworking is evident throughout much of this interval, although some unadulterated assemblages were isolated. These corroborate and occasionally refine the age assignments based on planktonic foraminifers. The interval contains a sequence spanning Subzone N4b to Zone N10. Unadulterated calcareous nannofossils from Zone $\mathrm{CN} 4$ at the top of this interval indicate that only the lower part of Zone N10 is present. The average rate of sediment accumulation for this interval is approximately $9.5 \mathrm{~m} / \mathrm{m}$.y. Examination of the rates for individual biostratigraphic units (Fig. 1) indicates relatively low rates ( $<4 \mathrm{~m} / \mathrm{m}$.y.) for Zones $\mathrm{N} 4$ and $\mathrm{N} 5$ and elevated rates ( $>20 \mathrm{~m} / \mathrm{m}$.y.) for Zones N7 and N8 (lower part).

Small quantities of nannofossil foraminifer chalk filling cracks in the upper surface of a manganese-stained piece of shallow-water carbonate in Sample 144-871C-2R-1, 0-2 cm (133.2 mbsf), contains abundant, well-preserved calcareous microfossils of early Oligocene age (P20/CP18). This chalk is separated from the overlying Subunit IB ooze by a disconformity with a minimum hiatus of approximately $8.8 \mathrm{~m} . \mathrm{y}$. A slightly older (P19/CP18) generation of pelagic limestone filling a boring into the top of the manganese crust occurs in Sample 144-871 A-15H-CC, $10-13 \mathrm{~cm}$.

Oxygen isotope data for planktonic foraminifer Zones N8 through N10 indicate that near-surface waters at this site were significantly warmer than normal for this time. Data from Lo-En Guyot (Opdyke and Pearson, this volume), a few degrees north of Limalok, do not show these anomalously warm paleotemperatures. This suggests the existence of a localized warm current over the site, perhaps analogous to the modern Equatorial Counter Current (Pearson and Shackleton, this volume). Oxygen isotope ratios of shallow-dwelling planktonic foraminifers become significantly more positive in Zones N10 through N12, suggesting cooling of the surface waters.

\section{LO-EN GUYOT (SITE 872)}

Site 872 is located at $10^{\circ} 05.85^{\prime} \mathrm{N}, 162^{\circ} 51.96^{\prime} \mathrm{E}$, in a water depth of $1084 \mathrm{~m}$, on the central summit plateau of Lo-En Guyot, in the northern Marshall Islands. Site surveys performed during the 1988 
SITE 871

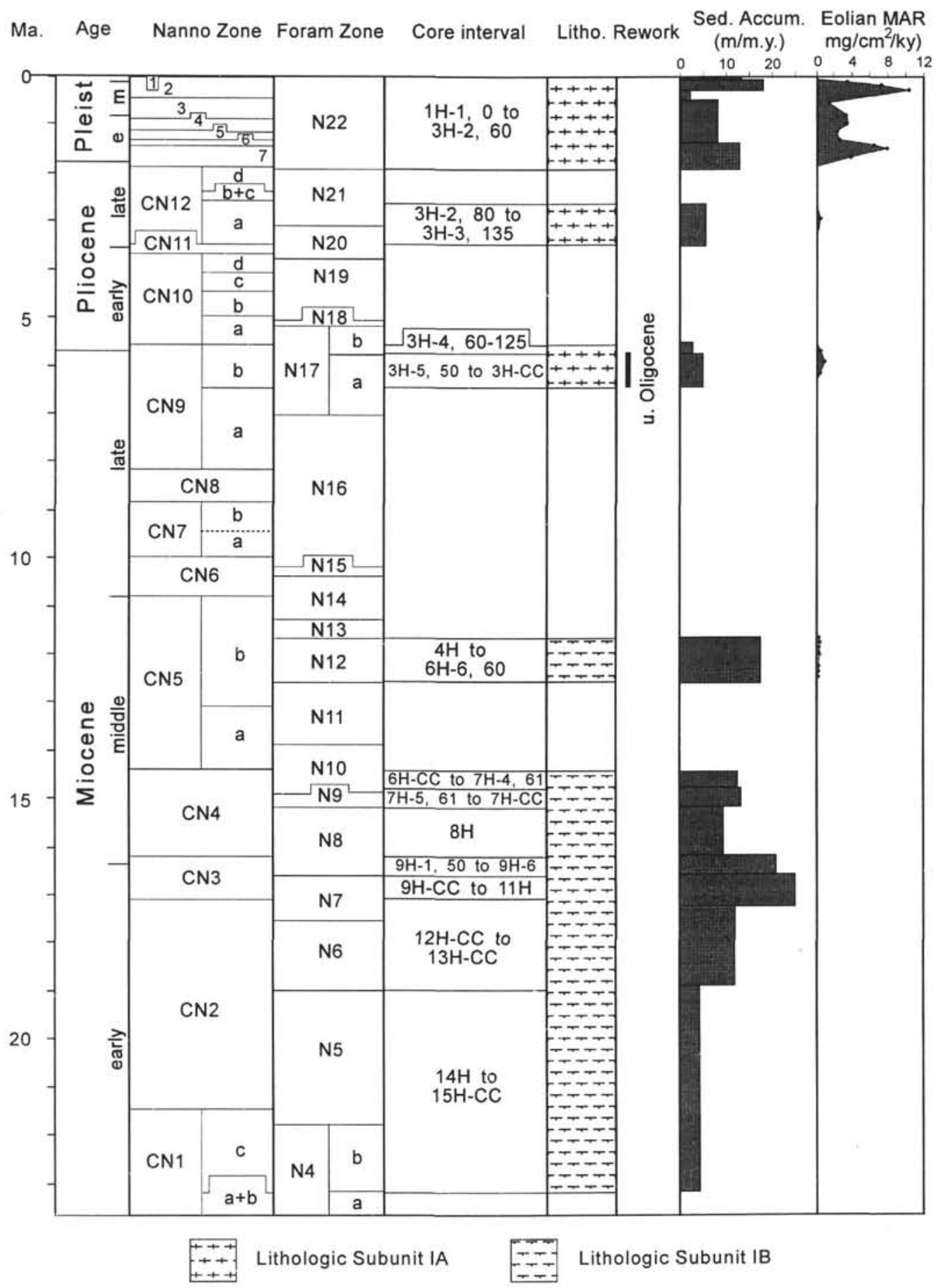

Figure 1. Summary of the upper Cenozoic stratigraphy of Site 871, Limalok Guyot. Quaternary nannofossil zones are those of Gartner (1977) and are denoted as follows: 1 = Emiliania huxleyi Acme Zone, 2 = Emiliania huxleyi Zone, 3 = Gephyrocapsa oceanica Zone, 4 = Pseudoemiliania lacunosa Zone, $5=$ small Gephyrocapsa Zone, 6 = Helicosphaera sellii Zone, and $7=$ Calcidiscus macintyrei Zone. Reworking column illustrates intervals of exhuma- tion and reworking of significantly older microfossils (thick line) as well as the age of the reworked material. Sediment accumulation rates are shown for each biostratigraphic interval that can be confidently assigned on the basis of calcareous microfossil content. Eolian mass accumulation rates (MAR) are calculated from data in Rack et al. (this volume) and the revised age model adopted in the present study. 
cruise of the Moana Wave (MW8805) indicate that Lo-En Guyot had the most complete pelagic cap sequence of the Marshall Island guyots. Lo-En Guyot shares the volcanic pedestal with the living Anewetak (formerly Eniwetok) Atoll. Unlike the other guyots drilled during Leg 144, Lo-En Guyot lacks a shallow-water carbonate platform complex on its summit plateau. The pelagic carbonate cap lies directly upon the volcanic edifice, separated only by a thin $(<1 \mathrm{~m})$ sequence of Upper Cretaceous and Paleogene sedimentary rocks including chalk, phosphate, phosphatized pelagic limestones filling fractures in the underlying basalt, and manganese-encrusted pebble conglomerates.

Holes $872 \mathrm{~A}$ and $872 \mathrm{C}$ were cored through the pelagic cap with the advanced hydraulic piston corer (APC) system. The most complete recovery $(98.5 \%)$ was obtained in Hole $872 \mathrm{C}$. In addition, excess water was removed from the core liners at Hole $872 \mathrm{C}$ by use of a "piglet" (weighted ring with a filter in the center). This method improved the preservation of sedimentary structures and minimized intracore mixing during curation. This hole was chosen for detailed biostratigraphic examination. The pelagic cap in Hole $872 \mathrm{C}$ is contained within lithologic Unit I. As at Limalok, this unit is divided into two subunits on the basis of its lithologic and geotechnical properties. Subunit IA (Core 144-872C-1H through Section 144-872C-4H-3; 0 $32.9 \mathrm{mbsf}$ ) consists of white foraminifer ooze interbedded with very pale brown nannofossil foraminifer ooze. In general, it is characterized by having higher bulk density, lower porosity, and lower water content than Subunit IB. Subunit IB (Section 144-872C-4H-4 through Core 144-872C-17H; 32.9-141.7 mbsf) consists of $108.8 \mathrm{~m}$ of homogenous, very pale brown foraminifer ooze.

Biostratigraphic analysis using planktonic foraminifers and calcareous nannofossils indicates that Subunit IA consists of three intervals of pelagic sediment separated by two disconformities (Fig. 2). Calcareous nannofossil biostratigraphy indicates that the upper interval (Core 144-872C-1H to Section 144-872C-2H-5; 0-26 mbsf) spans continuously the upper upper Pliocene (Subzone CN12b) through the Pleistocene. The sediment accumulation rate for the entire interval is approximately $7.7 \mathrm{~m} / \mathrm{m}$.y. Analysis of the sediment accumulation rates for each biostratigraphic unit indicates that the rates for most are $<10 \mathrm{~m} / \mathrm{m} . \mathrm{y}$., except for the Helicosphaera sellii Zone, where the sediment accumulation rate exceeded $30 \mathrm{~m} / \mathrm{m}$.y. This interval is separated from the underlying interval by a disconformity with a hiatus of at least 0.9 m.y. The middle interval in Subunit IA (Core 144-872C-3H; 18.5-28.0 mbsf) spans most of the lower Pliocene (Zones N18 through CN11; Fig. 2). Sediment accumulated at a rate of approximately $6 \mathrm{~m} / \mathrm{m}$.y. during the deposition of this interval. The disconformity separating the middle and lower interval in Subunit IA has a relatively short $(0.4$ m.y. $)$ hiatus. The basal interval (Sections 144-872C-4H-1 through $-4 \mathrm{H}-3 ; 28.0-32.9 \mathrm{mbsf}$ ) in Subunit IA contains upper Miocene (Subzone CN9b) nannofossil foraminifer ooze, which was deposited at a sediment accumulation rate of approximately $5.5 \mathrm{~m} / \mathrm{m} . \mathrm{y}$. Reworking is common in this interval, with planktonic foraminifers derived from upper Oligocene to lower Miocene Zones P22/N4 (e.g., Paragloborotalia pseudokugleri, Paragloborotalia kugleri, and the "Globigerina" ciperoensis group) being the most frequent forms. A few specimens of Globigerinoides bisphericus, Globorotalia mayeri, and Fohsella peripheroacuta indicate some reworking from the middle Miocene (N9-N10) also occurred. The middle and lower Miocene sediments of appropriate age are buried beneath at least $40 \mathrm{~m}$ and $65 \mathrm{~m}$, respectively, of sediment at this site. This indicates that these beds were exposed to erosion somewhere else nearby on the guyot summit plateau during the late Miocene.

Subunit IB consists of a thick $(108.8 \mathrm{~m})$ sequence of upper Oligocene to lower upper Miocene foraminifer ooze. Sedimentation was relatively continuous, with only four relatively minor hiatuses interrupting the sequence. The upper Miocene of Subunit IB consists of two intervals of pelagic sediment. The upper interval contains micro- fossils of Subzone N17a and CN9a. The lower interval includes sediments of Zones N15 through CN8. These two intervals are separated by a disconformity with a minimum hiatus of approximately $1.1 \mathrm{~m} . \mathrm{y}$. The sediment accumulation rates during both upper Miocene intervals was quite low $(<2 \mathrm{~m} / \mathrm{m}$.y.). Both intervals of the upper Miocene contain frequent reworked microfossils from the upper Oligocene to lower Miocene (Zones P22 and N4) and middle Miocene (N9-N10), as in the basal interval of Subunit IA. In addition, a single specimen of the Turonian planktonic foraminifer Dicarinella hagni occurs in Sample $144-872 \mathrm{C}-5 \mathrm{H}-4,14-16 \mathrm{~cm}$. This indicates that significantly older material was being reworked on Lo-En Guyot during the early late Miocene.

A thick sequence of lower and middle Miocene foraminifer oozes is separated from the upper Miocene by a disconformity corresponding to Zone N14 (Fig. 2). The minimum hiatus on this disconformity is approximately $0.9 \mathrm{~m} . \mathrm{y}$. The lower and middle Miocene sequence is relatively complete, with only one disconformity corresponding to Zone N9 (a hiatus of approximately $0.3 \mathrm{~m} . \mathrm{y}$.). Mixing and reworking is common throughout this sequence. This was caused, at least in part, by core handling procedures used with this very soupy foraminifer ooze. These problems are especially acute with the calcareous nannofossils, which could easily have moved through the entire core length during application of the piglet and subsequent vertical settling of the core sections. As a result, ages determined by examination of planktonic foraminifers are considered more reliable for this interval. Sediment accumulation rates within this interval are generally $<10 \mathrm{~m} / \mathrm{m}$.y., with the exception of the uppermost (N13) and lowermost $(\mathrm{CNla}+\mathrm{b})$ biostratigraphic units, where rates are significantly higher at approximately 70 and $25 \mathrm{~m} / \mathrm{m}$.y., respectively. The lowermost biostratigraphic unit in this interval $(\mathrm{CNla}+\mathrm{b})$ contains common, diverse assemblages of middle and upper Eocene planktonic foraminifers including Acarinina bullbrooki, Acarinina topilensis, Globigerinatheka subconglobata, and Hantkenina alabamensis. The basal Miocene is separated from the underlying upper Oligocene by a disconformity with a minimal hiatus.

The interval from Cores $144-872 \mathrm{C}-15 \mathrm{H}$ through $-17 \mathrm{H}$ contains upper Oligocene microfossil assemblages (Zones P21/P22 and $\mathrm{CP} 19)$. Sediment accumulation rates during this interval were relatively low (1.5-4 m/m.y.). Reworked middle and upper Eocene planktonic foraminifers, as in basal Miocene Core $144-872 \mathrm{C}-14 \mathrm{H}$, occur in Core 144-872C-15H.

\section{WODEJEBATO GUYOT (SITE 873)}

Site $873\left(11^{\circ} 53.84^{\prime} \mathrm{N}, 164^{\circ} 55.23^{\prime} \mathrm{E}\right)$ sampled the stratigraphic section from the central part of Wodejebato Guyot. Water depth at the site is $1335 \mathrm{~m}$. Wodejebato Guyot (formerly Sylvania Guyot) is located approximately $44 \mathrm{~km}$ northwest of Pikinni Atoll (formerly Bikini Atoll) in the Ralik Chain of the northern Marshall Islands (see site map preceding title page). These two edifices are located on the same volcanic pedestal and are connected by a volcanic ridge at a water depth of approximately $1500 \mathrm{~m}$. Although Pikinni Atoll is characterized by a thick sequence of Cenozoic shallow-water carbonates that continue to accumulate today, Wodejebato Guyot experienced only a brief period of Late Cretaceous carbonate platform sedimentation before it drowned near the end of the Maastrichtian. The drowning surface was covered by a thin series of pelagic limestones, phosphatized pelagic limestones, and manganese crusts during the Paleogene. Pelagic cap sediments began to accumulate in the early Miocene.

Drilling with the APC in Hole $873 \mathrm{~B}$ penetrated $54 \mathrm{~m}$ of pelagic ooze, for a total recovery of $83.7 \%$. The pelagic ooze was very soupy when brought on deck. As at Site 872, a piglet was employed (with some success) to reduce intraliner mixing. The pelagic cap sediments compose lithologic Unit I (Cores 144-873B-1H through -6H; 0-54.0 


\section{SITE 872}

Ma. Age Nanno Zone Foram Zone Core interval Litho. Rework Sed. Accum.

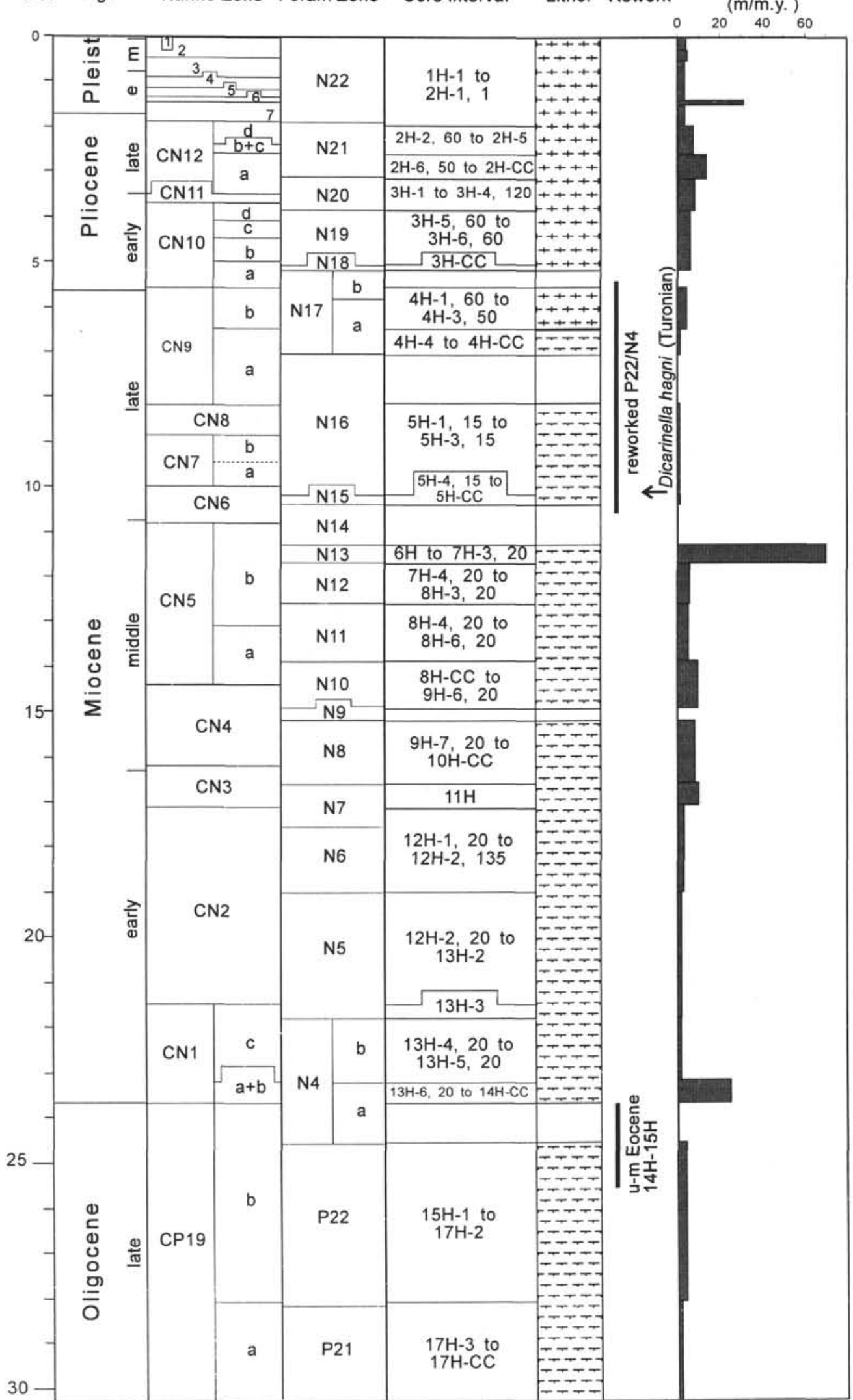

Figure 2. Summary of the upper Cenozoic stratigraphy of Site 872, Lo-En Guyot. See Figure I for explanation. 
mbsf). Two subunits (IA and IB) are recognized based on their lithological and geotechnical properties.

Subunit IA consists of $29 \mathrm{~m}$ of light gray nannofossil foraminifer ooze (Core 144-873B-1H through Sample 144-873B-4H-3, $82 \mathrm{~cm}$ ). It is composed of $60 \%-70 \%$ planktonic foraminifers and $30 \%-40 \%$ calcareous nannofossils and is $97 \%-99 \%$ calcium carbonate. This subunit is characterized by generally lower porosity $($ mean $=74 \%)$ and higher dry bulk density (mean $=0.78 \mathrm{~g} / \mathrm{cm}^{3}$ ) than underlying Subunit IB. The eolian component $(<63 \mu \mathrm{m})$ varies from $0.1 \%$ to $0.55 \%$, with values generally decreasing downward through Subunit IA. Subunit IB consists of $25 \mathrm{~m}$ of very pale brown foraminifer ooze. Planktonic foraminifers compose approximately $95 \%$ of the sediment. Calcareous nannofossils are only a minor component $(<5 \%)$ of this ooze. The ooze is well sorted, with a medium sand texture that indicates extensive winnowing before deposition. This winnowing is also evident in the reduced dry bulk density (mean $\left.=0.6 \mathrm{~g} / \mathrm{cm}^{3}\right)$ and increased porosity $($ mean $=78.5 \%$ ). Biostratigraphic analysis based on combined planktonic foraminifer and calcareous nannofossil age determinations indicates the presence of at least five intervals of temporally contiguous sediment separated by at least four disconformities (Fig. 3).

Subunit IA is divided biostratigraphically into at least two intervals of pelagic sediment separated by at least one disconformity. The upper interval of nannofossil foraminifer ooze (Core 144-873B-1H through Sample 144-873B-3H-4, $50 \mathrm{~cm} ; 0-21 \mathrm{mbsf}$ ) apparently spans the upper lower Pliocene to lower Pleistocene. A coherent sequence of planktonic foraminifer and calcareous nannofossils zones and subzones allows relatively high-resolution subdivision of this interval (Fig. 3). The top of the cored sequence (Sample 144-873B-1H$1,0-5 \mathrm{~cm}$ ) contains a nannofossil assemblage characteristic of the lower Pleistocene Helicosphaera sellii Zone. This suggests that the middle and upper Pleistocene are missing at this site. However, downhole contamination that occurs within Cores 144-873B-1H and $-2 \mathrm{H}$ contains Emiliania huxleyi, a species characteristic of the upper Pleistocene. This suggests that the upper part of the section was blown away by drilling operations. This interval of Subunit IA continues down through the upper Pliocene and into the upper lower Pliocene (N19/CN10d). The average sediment accumulation rate through this interval is approximately $8 \mathrm{~m} / \mathrm{m}$.y. Examination of the sediment accumulation rates for each biostratigraphic unit indicates a very high rate of accumulation during the Helicosphaera sellii Zone (early Pleistocene), with a secondary maximum during Subzone $\mathrm{CN} 12 \mathrm{~b}+\mathrm{c}$ (late Pliocene). Estimations of the eolian mass accumulation rate (Fig. 3) indicate a peak rate of eolian accumulation during the Helicosphaera sellii Zone of approximately $20 \mathrm{mg} / \mathrm{cm}^{2} / \mathrm{k} . \mathrm{y}$. Lesser maxima of eolian mass accumulation occurred during Subzone $\mathrm{CN} 12 \mathrm{~b}+\mathrm{c}$ and Zone N20. Rare diatoms occur in the upper two cores of this interval, but only zeolitic alteration products and poorly preserved radiolarians occur in the rest of the interval.

The lower biostratigraphic interval of Subunit IA is separated from the upper interval by a disconformity with a hiatus of at least 0.9 m.y. The age of the lower interval is bracketed by the basal assignment of Zone N18 and the upper assignment of Subzone CN10a. This interval appears to represent a brief pulse of sediment accumulation during the latest Miocene. The linear sediment accumulation rate is at least $30 \mathrm{~m} / \mathrm{m}$.y. This pulse of high sediment accumulation was not accompanied by significant eolian influx. The base of Subunit IA is separated from the top of the foraminifer oozes of Subunit IB by a disconformity with a substantial hiatus of at least 6.3 m.y.

Lithologic Subunit IB consists largely of two intervals of middle Miocene foraminifer ooze separated by a disconformity. Sample 144873B-4H-4, 37-38 cm, through Core 144-873B-5H (30.4-44.5 mbsf) contain planktonic foraminifer assemblages assignable to Zones $\mathrm{N} 12 / \mathrm{N} 13$. Core 144-873B-5H contains a significant component of reworked foraminifers, including lower middle Miocene forms and rare specimens of lower Miocene taxa. The lower middle Miocene forms are derived probably from the immediately underlying interval. The lower Miocene specimens, on the other hand, are derived from sediment that was not preserved or recovered at this site. The lower middle Miocene ooze in Core 144-873B-6H (44.5-54.0 mbsf) is assigned to Zones N8 and N9. Reworking is also severe in this core. The linear sediment accumulation rate for both of these intervals in Subunit IB is approximately $6-8 \mathrm{~m} / \mathrm{m}$.y. The accumulation of eolian sediment was miniscule $\left(2-4 \mathrm{mg} / \mathrm{cm}^{2} / \mathrm{k} . \mathrm{y}\right.$.). This is probably the result of the substantial winnowing evident in this sediment.

Core 144-873B-7H penetrated $4.0 \mathrm{~m}$ (54.0-58.0 mbsf) but recovered only two pebbles of manganese crust with attached nannofossil foraminifer ooze. Nannofossils from this ooze contain assemblages indicative of Subzones $\mathrm{CNla}+\mathrm{b}$. The presence of common Sphenolithus delphix suggests Subzone CN1b, following the work of Rio et al. (1990). This lower Miocene sediment may have been the source of the reworked microfossils found in the overlying intervals, but the lack of recovery precludes certainty.

\section{MIT GUYOT (SITE 878)}

MIT Guyot is an isolated feature near the Wake Group. Site 878 is located at $27^{\circ} 19.14^{\prime} \mathrm{N}, 151^{\circ} 53.03^{\prime} \mathrm{E}$, in a water depth of $1323.2 \mathrm{~m}$, on the northeastern part of the MIT Guyot near its southern edge. Platform drowning in the late Albian (Erba et al., this volume) was followed by the deposition of manganese-encrusted hardgrounds during the late Albian through at least the early Eocene (Watkins et al., this volume). Unlike the Marshall Islands guyots, MIT Guyot lacks a thick pelagic cap. Its upper surface is characterized by a karst topography developed in the shallow-water carbonates (van Waasbergen and Winterer, 1993). Pelagic ooze is present only in surficial depressions (Premoli Silva, Haggerty, Rack, et al., 1993). Approximately $3.2 \mathrm{~m}$ of soupy, structureless pelagic sediment was recovered in Hole $878 \mathrm{~A}$. This sediment consists of intermixed foraminifer nannofossil ooze, nannofossil ooze, and manganese nodules. Nannofossil biostratigraphy indicates that the ooze is composed of material from at least three distinct ages: early Pleistocene $(H$. sellii and $C$. macintyrei zones), late Pliocene (CN12a), and late Miocene to earliest Pliocene (CN9b).

\section{DISCUSSION}

The three Marshall Islands guyots (Limalok, Lo-En, and Wodejebato) have thick upper Cenozoic pelagic caps that cover most of their respective summit plateaus. Each of the three Marshall Island guyots had distinctly different histories before the initiation of pelagic cap sedimentation. Limalok Guyot was the site of a thriving carbonate platform complex from the Paleocene through the middle Eocene. Following its drowning, currents apparently swept the guyot summit nearly clean of pelagic sediment throughout the middle Eocene through Oligocene, leading to the development of a manganese-encrusted hardground. Pelagic cap sedimentation began in earnest during the early Miocene. The shallow-water carbonate platform on Wodejebato Guyot was significantly older (late Campanian through Maastrichtian). The drowning event was followed by development of a complex manganese-encrusted hardground throughout the Paleocene through early Oligocene. Pelagic cap sedimentation began in the earliest Miocene and continued sporadically through the late Cenozoic. Lo-En Guyot lacked the well-developed carbonate platform of the other two guyots, although shallow-water carbonates of Albian age have been dredged from the margins of the guyot (Lincoln et al., 1993). Phosphatized pelagic carbonate and manganese crusts indicate a long period of exposure (Late Cretaceous through early Oligocene) before the initiation of pelagic cap accumulation during the late Oligocene. 
SITE 873

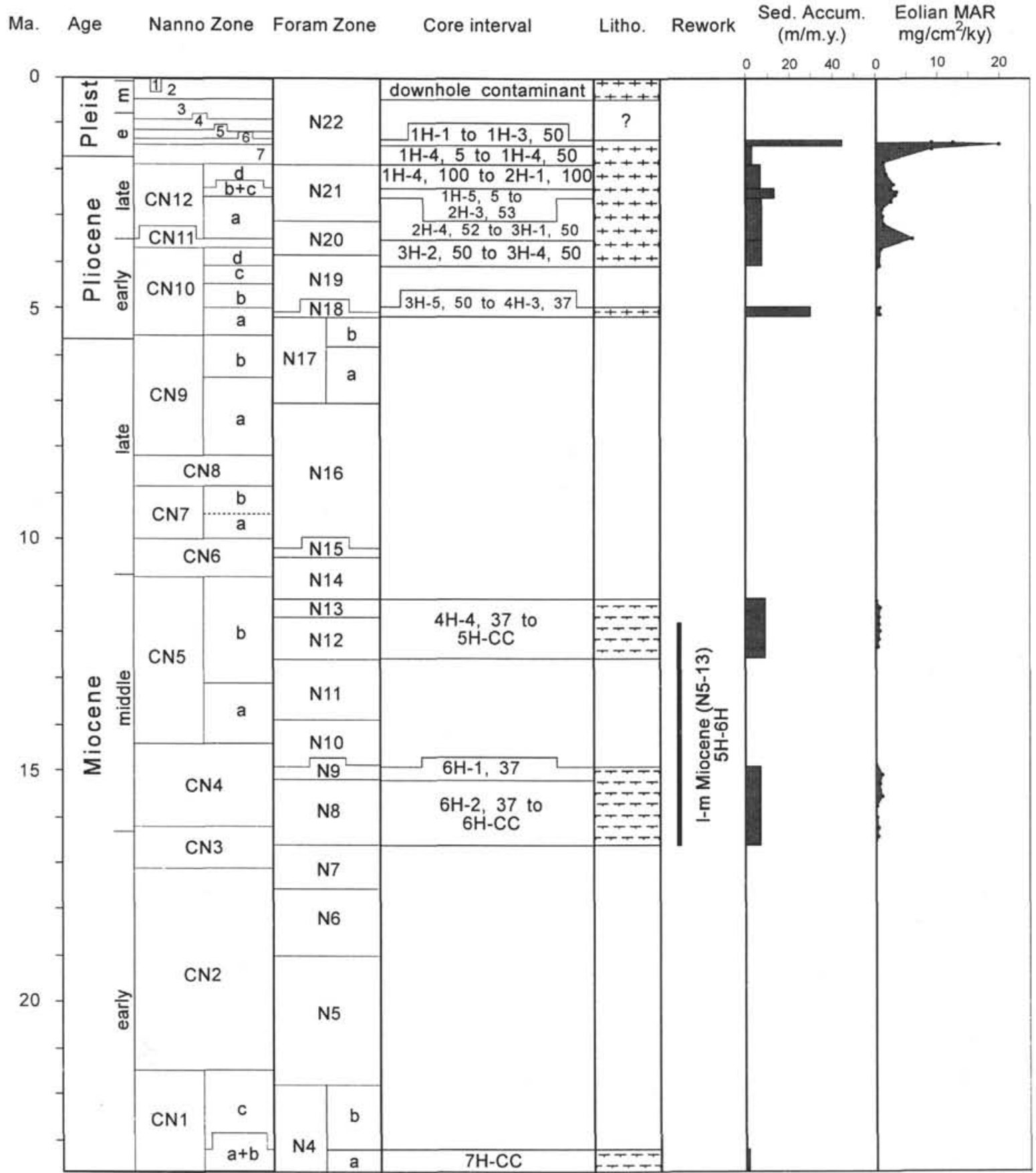

Figure 3. Summary of the upper Cenozoic stratigraphy of Site 873, Wodejebato Guyot. See Figure 1 for explanation.

Despite these differences in the overall development of the guyots, marked similarities occur in the pattern of development of the upper Cenozoic pelagic caps. These similarities include the general lithologic sequence, the patterns of reworking and mixing, and the timing of sediment accumulation and erosion or nondeposition.

The pelagic caps of all three guyots are easily divisible into two lithologic subunits (IA and IB) based on multiple sedimentologic and geotechnical criteria. In each case (Fig. 4), a white to pale brown foraminifer ooze (Subunit IB) underlies a pale brown nannofossil foraminifer ooze (Subunit IA). Subunit IB invariably exhibits evidence of significant winnowing, yielding a medium sand texture with relative- ly low bulk density, high porosity, and high water content. Mixing and reworking is common in parts of Subunit IB. This subunit is relatively thick on Limalok (107.2 m) and Lo-En (113.4 m) but much thinner on Wodejebato $(25.3 \mathrm{~m})$. Subunit IA contains significantly more fine-grained sediment than Subunit IB. This is reflected in its higher bulk density, lower porosity, and lower water content.

Although Eolian sediment is more common in Subunit IA (as discussed below), reworking and mixing (excluding downhole contamination) are rare to nonexistent in this subunit. The thickness of Subunit IA is remarkably uniform among the three guyots: $26.5,30.2$, and $29.0 \mathrm{~m}$ at Limalok, Lo-En, and Wodejebato, respectively. The 


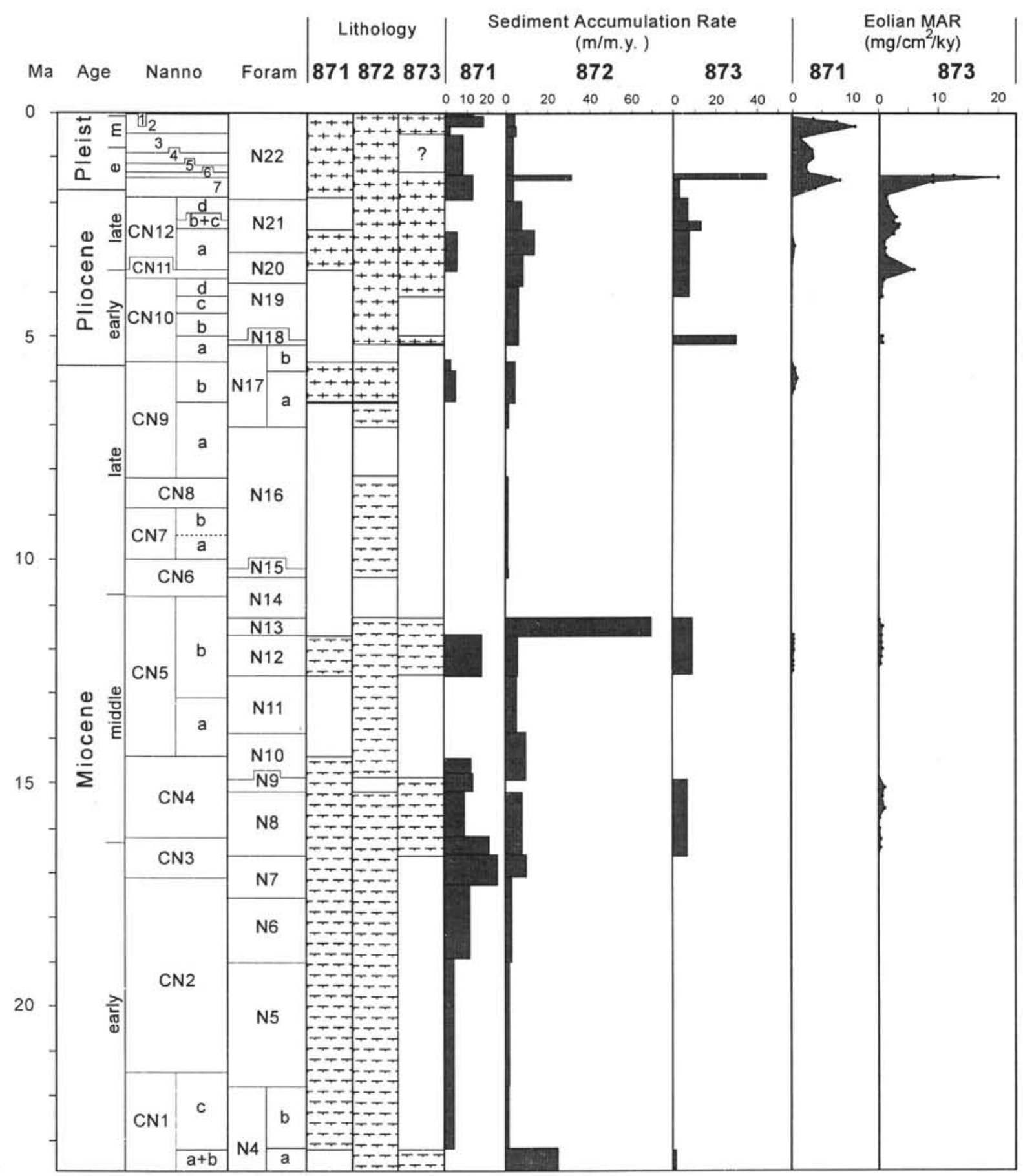

Figure 4. Comparison of sediment accumulation rates and eolian mass accumulation rates (MAR) for Sites 871 (Limalok), 872 (Lo-En), and 873 (Wodejebato).

oldest sediment in Subunit IA is late Miocene to earliest Pliocene in age at all three guyots. It is underlain by a disconformity with a significant hiatus at Sites 871 and 873 . This boundary is contained within a temporally contiguous sequence at Site 872 and can be precisely dated as within planktonic foraminifer Subzone N17a, coincident with the $\mathrm{CN} 9 \mathrm{a} / \mathrm{b}$ calcareous nannofossil subzonal boundary. This corresponds approximately to an age of 6.9 m.y. (Cande and Kent, 1992).

Reworked and mixed microfossil assemblages are common throughout Subunit IB. Mixing in the well-winnowed foraminifer sands results, in part, from the very soupy nature of the sediment, its high water content, and the disturbance by drilling and curation. However, this mixing often occurs through multicore intervals, which indicates that reworking and mixing was an inherent part of the deposition of this sediment. Reworking across disconformities is common. Mixing is most common in intervals with lower sediment accumulation rates, especially those in the Miocene.

Two periods of more profound reworking are evident in the pelagic caps. During these episodes, significantly older microfossils were reworked into the foraminifer oozes. At Site 872 , middle to late 
Eocene foraminifers were reworked in the latest Oligocene (Fig. 2). A second episode of profound reworking occurred during the late $\mathrm{Mi}$ ocene. On Limalok Guyot (Site 871), late Oligocene foraminifers and nannofossils were exhumed and reworked during Zone N17. More than $100 \mathrm{~m}$ of sediment separate the Zone N17 sediment from the uppermost Oligocene sediment that could serve as a source for the reworking. This indicates significant excavation of the pelagic cap near or on the summit plateau. On Lo-En Guyot (Site 872), reworked planktonic foraminifers and calcareous nannofossils of late Oligocene to early Miocene (P22-N4) age were reworked into foraminifer oozes during the late Miocene. In this case, these microfossils were reworked into the sediments of Zone N15 to Subzone N17a, indicating a protracted period (approximately $5 \mathrm{~m} . \mathrm{y}$.) of significant exhumation and reworking.

At Site 872, source sediments of the appropriate age to supply the reworked specimens occur at least $60 \mathrm{~m}$ below the upper Miocene. More significantly, a specimen of the Turonian planktonic foraminifer Dicarinella hagni occurs in the base of the section that contains the reworked forms. At Site 872, specimens of this age were found (in situ) only deep within cracks in the top of the basaltic edifice (Premoli Silva, Haggerty, Rack, et al., 1993). This suggests excavation down to the bare volcanic rock on or near the summit plateau.

Correlation of the stratigraphic sections for the Neogene of the three guyot sites (Fig. 4) indicates that each site has its own unique characteristics. Site 872 has the most continuous upper Cenozoic stratigraphic sequence, despite the fact that it is almost $10 \mathrm{~m}$ thinner than the less complete upper Cenozoic sequence at Site 871. The upper Cenozoic section at Site 873 is the most incomplete, which is not unexpected considering that it is less than half the thickness of the other two sites. Nevertheless, distinct parallels are evident among the upper Cenozoic sediment accumulation histories of these guyots.

Examination of the age vs. depth curves for these three sections (Fig. 5) indicates that Miocene sediment accumulation began with a brief pulse of accumulation and preservation in the earliest Miocene $(\mathrm{CNla}+\mathrm{b} / \mathrm{N} 4 \mathrm{a})$, followed by a long period of little or no accumulation during the early and middle early Miocene. Sediment accumulation rates increased markedly during the late early to early middle Miocene (CN3-CN4/N7-N9). Large-scale mixing of sediment occurred during this deposition episode. The middle middle Miocene was characterized by slower sediment accumulation (Site 872 ) or nondeposition (Sites 871 and 873).

A brief, late middle Miocene pulse of winnowed ooze accumulation occurred during the late middle Miocene (N12-N13/CN5b). This was followed by a long period with little or no sediment accumulation during the late middle to middle late Miocene (N13-N16/ CN6-CN9a). A major change occurred during the latest Miocene, when deposition of winnowed foraminifer ooze gave way to nannofossil ooze deposited under quieter current conditions. This transition is marked by the reworking of significantly older microfossils. Following a brief hiatus near the Miocene/Pliocene boundary $(\mathrm{CN} 10 \mathrm{a} /$ $\mathrm{N} 17 \mathrm{~b}$ ), more continuous deposition of fine-grained nannofossil and foraminifer nannofossil ooze characterized most of the Pliocene and Quaternary.

Eolian sediments are a significant component of the sediment only in lithologic Subunit IA (Fig. 4). Data on eolian mass accumulation rates (EMAR) are available from Site 871 for the latest Pliocene to Quaternary and from Site 873 for the mid-Pliocene through early Pleistocene. The records for these two sites overlap in the uppermost Pliocene to lower Pleistocene, and allow the construction of a composite record. This composite suggests five maxima in EMAR during the mid-Pliocene through Quaternary. At Site 871, a peak of approximately $10 \mathrm{mg} / \mathrm{cm}^{2} / \mathrm{k}$.y. occurs in the Emiliania huxleyi Zone of middle Pleistocene age. Lesser maxima $\left(4-5 \mathrm{mg} / \mathrm{cm}^{2}\right.$ / k.y.) appear evident in the vicinity of the Gephyrocapsa oceanical Pseudoemiliania lacunosa zonal boundary. Both records show significant increases in EMAR (up to $20 \mathrm{mg} / \mathrm{cm}^{2} / \mathrm{k}$.y. at Site 873 ) during

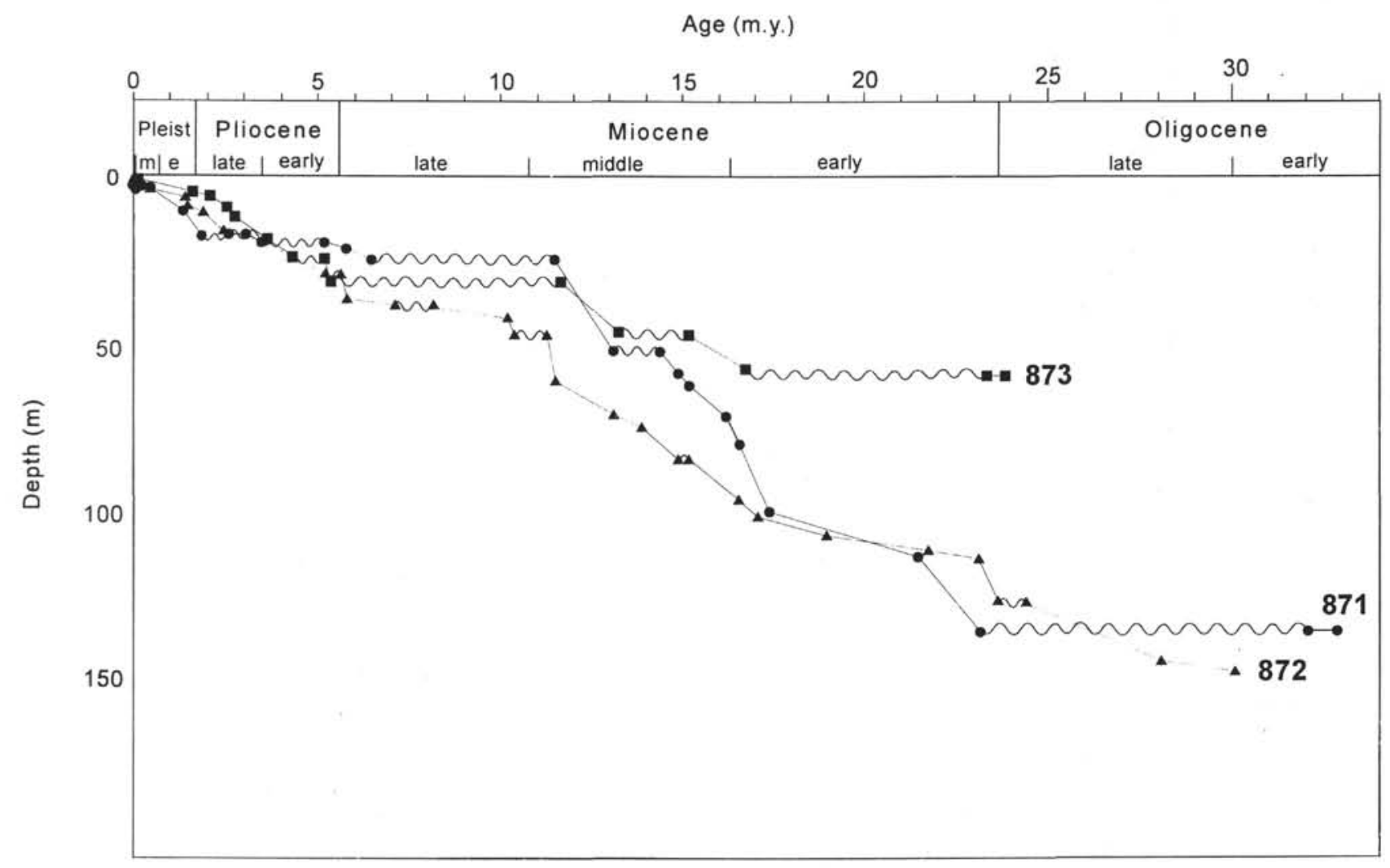

Figure 5. Age vs. depth plots for Sites 871 (Limalok), 872 (Lo-En), and 873 (Wodejebato). Disconformities denoted by wavy lines. 
the Helicosphaera sellii Zone (lower Pleistocene). Two maxima are evident in the Pliocene record from Site 873. These occur near the upper and lower boundary of calcareous nannofossil Subzone CN12a,

MIT Guyot, near the Wake Group, lacks a pelagic cap and preserves upper Cenozoic pelagic carbonate only in sheltered surface depressions. Little can be determined from the highly disturbed $3.2 \mathrm{~m}$ of pelagic ooze that was recovered. However, it is noteworthy that the three ages identified from this ooze are represented also at the Marshall Islands guyots. The late Pliocene (CN12a) and early Pleistocene (Helicosphaera sellii Zone) ages correlate to distinct intervals of higher linear sediment accumulation rates on the Marshall Islands guyots (Fig. 4). The late Miocene to earliest Pliocene age (CN9b) correlates to the oldest sediment in lithologic Subunit IA on Limalok and Lo-En guyots. This subzone is absent in the thinner section on Wodejebato Guyot.

\section{Construction of Northwestern Pacific Pelagic Caps}

Pearson (this volume) has hypothesized that construction of the pelagic caps proceeds by a three-phase process. During Phase A, current velocities across the guyot summit plateau are great enough to allow sediment accumulation only in topographically sheltered areas. Elsewhere on the summit plateau, manganese-encrusted hardgrounds accumulate. Phase B involves deposition of the lower pelagic cap sequence of winnowed foraminifer ooze. Initial sediment accumulation is restricted largely to the central portion of the summit plateau (Pearson, this volume, fig. 10). This is probably caused by the action of tidal currents, as Lonsdale et al. (1972) noted on Horizon Guyot. During Phase $\mathrm{C}$, sediment accumulation progressively spreads to the margin of the guyot, resulting in a mature pelagic cap. Seismic profiles of Limalok, Lo-En, and Wodejebato (Premoli Silva, Haggerty, Rack, et al., 1993) clearly indicate a series of domed, concave-downward units that sequentially overstep their underlying units at the margins of the pelagic cap or truncate against the side of topographically high (presumed) volcanic cones. The latter is well illustrated in Premoli Silva, Haggerty, Rack, et al. (1993, "Site 872 " chapter, fig. 4). This is the type of constructional stratigraphic geometry predicted by the Pearson hypothesis.

\section{Comparison with Other Tropical Western Pacific Guyots}

The three Marshall Islands Group pelagic cap sections are, by far, the best available records of sedimentation on tropical Western Pacific guyots. Compilation of data from these three guyots yields a fairly coherent pattern of pelagic cap construction. However, it is difficult to judge how typical these patterns of pelagic cap construction are based only on the three Leg 144 guyots. In addition, the lack of a pelagic cap on MIT Guyot must also be explained. Data from four other guyots drilled by the Deep Sea Drilling Project (DSDP) and ODP are available for comparison to the Leg 144 sites. Although the records from these guyots are not of the same high quality as the Leg $144 \mathrm{sec}-$ tions, because of either the drilling procedures used (DSDP 171 and $200)$ or the thinness of the sections recovered (ODP 865 and 866), they do offer some basis for evaluating the patterns deduced from the Leg 144 pelagic caps. The upper Cenozoic sections from these four guyots are briefly described below.

DSDP Site 200 is located at $12^{\circ} 50.2^{\prime} \mathrm{N}, 156^{\circ} 47.0^{\prime} \mathrm{E}$ on Ita Mai Tai Guyot on the eastern end of the Caroline Abyssal Plain. Water depth at the site is $1554 \mathrm{~m}$. Hole 200 penetrated approximately $114 \mathrm{~m}$ of winnowed, white to very pale orange foraminifer ooze with a total recovery of approximately $31 \%$ (Heezen, MacGregor, et al., 1973). Compilation of planktonic foraminifer (Krasheninnikov and Hoskins, 1973) and calcareous nannofossil (Hekel, 1973) data indicates the presence of three coherent intervals of upper Cenozoic sediment (Fig. 6). The first interval includes an apparently continuous se- quence of uppermost Pliocene and Quaternary sediment (N22/ CN13-CN15). The second interval contains a sequence of upper Miocene $(\mathrm{CN} 8 / \mathrm{N} 16)$ through upper Pliocene $(\mathrm{CN} 12 \mathrm{a} / \mathrm{N} 21)$ oozes. Krasheninnikov and Hoskins (1973) report profound reworking of Eocene planktonic foraminifers during the deposition of the upper Miocene to lowermost Pliocene sequence (N15-N18). The third interval consists of an upper lower Miocene (N7/CN2) through lower middle Miocene (N9/CN4) sequence of foraminifer ooze.

ODP Site $865\left(18^{\circ} 26.4^{\prime} \mathrm{N}, 179^{\circ} 33.3^{\prime} \mathrm{W}\right)$ is located near the summit margin of Allison Guyot in the Mid-Pacific Mountains. Water depth at the site is $1518 \mathrm{~m}$. Approximately $14.5 \mathrm{~m}$ of upper Cenozoic nannofossil ooze was cored with nearly $100 \%$ recovery. Biostratigraphic data in Sager, Winterer, Firth, et al. (1993) indicates that three intervals of upper Cenozoic pelagic ooze were recovered (Fig. $6)$. The youngest consists of a thin $(<1 \mathrm{~m})$ interval of late Quaternary age (CN15/N22), with evidence of mixing or reworking of slightly older material. A second interval of approximately $8 \mathrm{~m}$ contains nannofossil foraminifer ooze of late early to early middle Miocene age (CN3-CN4/N7-N10). A lower 6.5-m interval contains ooze of early early Miocene $(\mathrm{CNl} \mathrm{a}+\mathrm{b} / \mathrm{N} 4)$ age. However, it is clear from seismic reflection profiles that Site 865 is located away from the thickest accumulation of upper Cenozoic pelagic sediment (Sager, Winterer, Firth, et al., 1993, fig. 56). As a result, the section from Site 865 is not representative of the complete sequence in the pelagic cap.

DSDP Site 171 on Horizon Guyot is located at $19^{\circ} 07.9^{\prime} \mathrm{N}$, $169^{\circ} 27.6^{\prime} \mathrm{W}$ in the Mid-Pacific Mountains. Water depth at Site 171 is $2290 \mathrm{~m}$. The upper Cenozoic section at Site 171 was spot-cored, taking a core on every other $9 \mathrm{~m}$ advance. The first three cores, representing a total penetration of $55 \mathrm{~m}$, contain the Neogene section. All core barrels were recovered full, so that total recovery over the entire interval drilled $(55 \mathrm{~m})$ was $50 \%$. The Neogene section consists of approximately $55 \mathrm{~m}$ of very pale brown foraminifer nannofossil ooze (Winterer, Ewing, et al., 1973). Compilation data for planktonic foraminifers (Douglas, 1973) and calcareous nannofossils (Roth, 1973) indicates six distinct intervals of pelagic sediment accumulation and preservation (Fig. 6).

The completeness of the Quaternary cannot be ascertained from the drilling results in Hole 171 because coring began at a depth of 5 mbsf (Winterer, Ewing, et al., 1973). However, the presence of lower Pleistocene (N22/CN13-14a) at 5 mbsf suggests that it is relatively complete. The Pliocene is represented by two intervals of sediment that are assigned to nannofossil Subzones CN12a (late Pliocene) and CN10b (early Pliocene). These two intervals of sediment, dated as Pliocene, are characterized by significant mixing and reworking of late Miocene and, to a lesser degree, Eocene planktonic foraminifers (Winterer, Ewing, et al., 1973). Three intervals of Miocene sediment were recovered. These belong to the middle middle Miocene (N12$\mathrm{N} 13$ ), the lower middle Miocene (CN4), and the lower lower Miocene (CN1).

Resolution Guyot, in the Mid-Pacific Mountains, was drilled at ODP Site $866\left(21^{\circ} 20.0^{\prime} \mathrm{N}, 174^{\circ} 18.9^{\prime} \mathrm{E}\right)$. Water depth at the site is $1362 \mathrm{~m}$. Approximately $7.5 \mathrm{~m}$ of nannofossil foraminifer ooze was drilled and recovered from Hole $866 \mathrm{~B}$. Biostratigraphic data from Sager, Winterer, Firth, et al. (1993) suggest that three intervals of pelagic sediment accumulation are contained within this ooze (Fig. 6). The upper interval consists of approximately $1.17 \mathrm{~m}$ of Quaternary $(\mathrm{CN} 15 / \mathrm{N} 22)$ ooze. This is underlain by a thin interval of lower Pleistocene ooze (CN13). The lower interval contains approximately 3.5 $\mathrm{m}$ of mid-Pliocene nannofossil foraminifer ooze $(\mathrm{CN} 10 \mathrm{a} / \mathrm{N} 20-\mathrm{N} 21)$.

Although the three Leg 144 guyots clearly exhibit a change in sediment type from coarse, winnowed foraminifer ooze (Miocene) to fine-grained nannofossil foraminifer ooze (Pliocene through Quaternary), the quality of the data from the other guyots is too poor to test the universality of this trend. However, the broad pattern of sediment accumulation is very similar among the guyots (Fig. 6), as described below. 


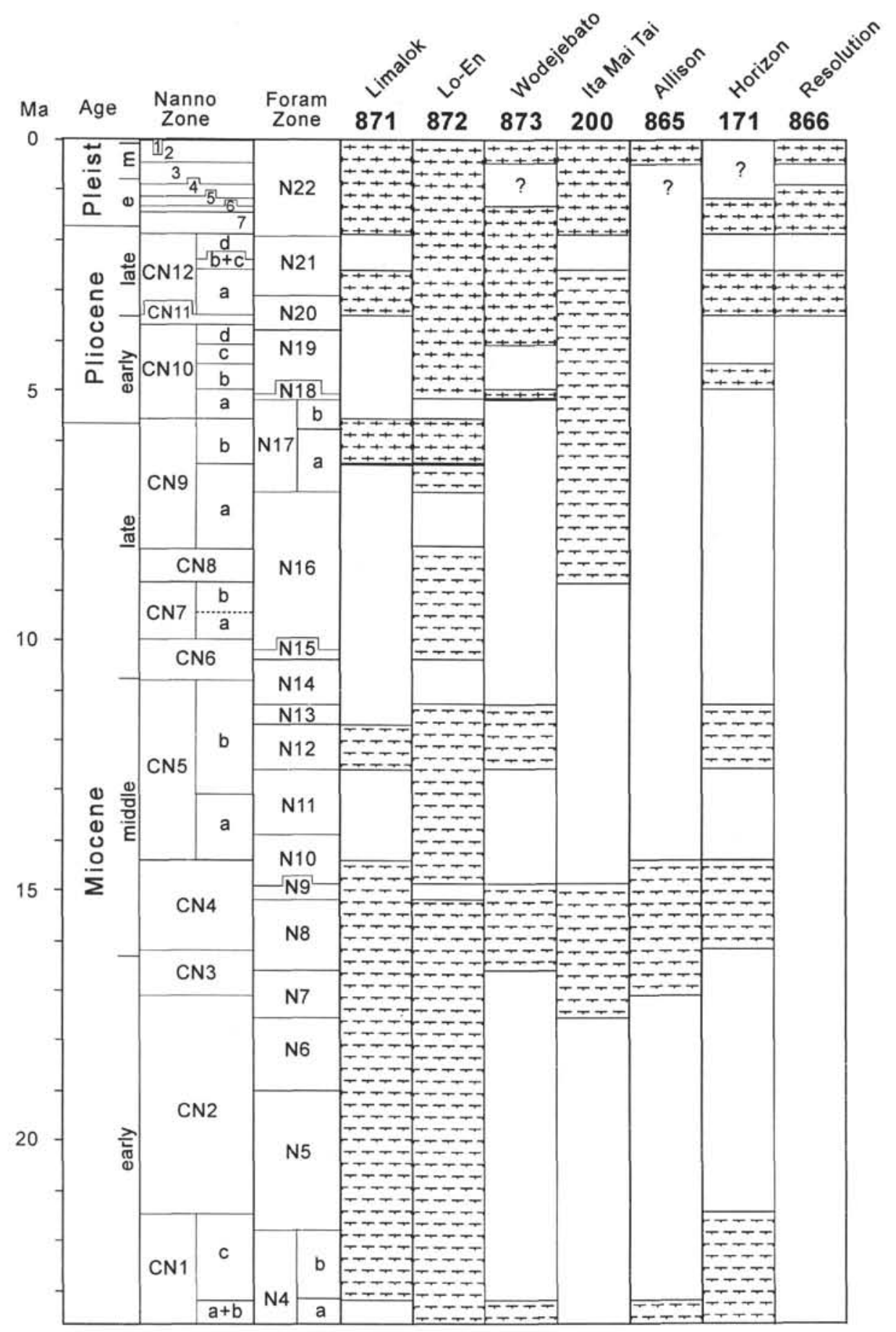

Figure 6. Late Cenozoic stratigraphic records from guyots in the Marshall Islands and Mid-Pacific Mountains. Stratigraphic information for Horizon Guyot (Site 171), Mid-Pacific Mountains, from Douglas (1973) and Roth (1973). Stratigraphic information for Ita Mai Tai Guyot (Site 200) from Krasheninnikov and Hoskins (1973) and Hekel (1973). Stratigraphic data for Allison (Site 865) and Resolution (Site 866) guyots from Sager, Winterer, Firth, et al. (1993).

The earliest Miocene pulse of sediment accumulation seen on the Leg 144 guyots is also preserved on Horizon and Allison guyots. The middle early Miocene period of little or no sediment accumulation, evident on the Leg 144 guyots, is represented only by disconformities in the other four guyot sections. The late early to early middle Miocene (CN3-CN4) episode of foraminifer ooze accumulation on Limalok, Lo-En, and Wodejebato guyots is also expressed on Horizon, Ita Mai Tai, and Allison guyots. This accumulation episode is followed by a disconformity on all but Lo-En Guyot. The middle middle Miocene pulse of winnowed foraminifer ooze accumulation seen on the Leg 144 guyots is also evident in the record at Site 171 (Horizon Guyot). Mixing of microfossil assemblages of different ages is common in this interval on all the guyots where it is represented. This mixing, and the winnowed nature of this sediment, indicate significant current activity on the guyot summit plateaus during the middle middle Miocene. 
The general late Miocene period of little or no accumulation is represented by a disconformity on Horizon, Allison, and Resolution guyots. Sediment accumulation rates during the late Miocene on Ita Mai Tai Guyot were quite low ( $<5 \mathrm{~m} / \mathrm{m}$.y.; Hekel, 1973). An early Pliocene pulse recorded as the last episode of winnowed ooze sedimentation on the Leg 144 guyots is also recorded in the sections on Horizon and Ita Mai Tai guyots. This pulse is unique in that significantly older microfossils are reworked into the ooze at several sites. Eocene planktonic foraminifers occur as reworked elements on Horizon and Ita Mai Tai guyots. Oligocene reworked microfossils occur in this interval on Limalok and Lo-En guyots. In addition, a Turonian planktonic foraminifer occurs as a reworked element on Lo-En Guyot. The source beds for these reworked fossils lie at the base of the pelagic cap sections on their respective guyots. These data indicate that the pelagic caps were profoundly eroded on part of the summit plateaus during the late Miocene.

Seismic reflection transects across the guyot plateaus on Limalok and Lo-En (Premoli Silva, Haggerty, Rack, et al., 1993) show no indications of significant incisements into the central summit plateau area. This suggests erosion at the outer margins of the pelagic cap during these episodes. The higher rates of sediment accumulation during the mid-Pliocene (CN12a) recorded on the Leg 144 guyots is evident also on Horizon, Ita Mai Tai, and Resolution guyots. This episode of accumulation was followed by a hiatus on Horizon, Ita Mai Tai, and Resolution guyots. All seven guyots contain some Quaternary sediment, although the differing coring procedures and problems make direct comparison among them difficult.

\section{The Decay of Northwestern Pacific Pelagic Caps}

Data on the modern summit plateau elevation (as represented by site water depths), latitude, thickness, and stratigraphic completeness of the upper Cenozoic of the seven pelagic caps drilled by DSDP and ODP were compiled (Table 1) and analyzed in an effort to examine the mechanisms controlling pelagic cap construction and preservation. Data from Allison Guyot (Site 865) was not used because the site is located at the margin of the upper Cenozoic pelagic cap and, therefore, contains a section that is stratigraphically unrepresentative. It should be noted, however, that the statistical correlations discussed below are sufficiently robust that inclusion of the Site 865 data does not alter the results by a significant degree.

No statistical relationship exists between modern plateau elevation and either thickness or stratigraphic completeness. Indeed, aside from the trivial correlation of thickness and stratigraphic completeness (i.e., thicker sections tend to be more complete), only one relationship is statistically significant. The thickness of the upper Cenozoic pelagic caps and their present-day latitudes are highly correlated $(r=0.908 ; P<0.01)$, with thickness decreasing toward the north. The regression line derived from the analysis (Fig. 7) predicts that the thickness of the pelagic cap should have a maximum thickness of approximately $180 \mathrm{~m}$ at the equator and decrease to zero at approximately $25.7^{\circ} \mathrm{N}$. Seismic reflection data from 21 western Pacific guy-

Table 1. Water depths, latitudes, thicknesses, and stratigraphic completeness for the seven guyots discussed.

\begin{tabular}{ccccc}
\hline Site & $\begin{array}{c}\text { Water depth } \\
(\mathrm{m})\end{array}$ & $\begin{array}{c}\text { Latitude } \\
\left({ }^{\circ} \mathrm{N}\right)\end{array}$ & $\begin{array}{c}\text { Thickness } \\
(\mathrm{m})\end{array}$ & $\begin{array}{c}\text { Completeness } \\
(\%)\end{array}$ \\
\hline 878 & 1323 & 27.3 & 3.2 & 6 \\
171 & 2290 & 19.1 & 55 & 21 \\
200 & 1554 & 12.8 & 144 & 31 \\
866 & 1362 & 21.3 & 7.5 & 7 \\
871 & 1255 & 5.5 & 152 & 38 \\
872 & 1084 & 10.1 & 141.7 & 59 \\
873 & 1335 & 11.8 & 54.0 & 20 \\
865 & 1518 & 18.4 & 14.5 & 11 \\
\hline
\end{tabular}

Notes: Thickness $=$ thickness of upper Cenozoic. Stratigraphic completeness $=$ percent age of late Cenozoic time represented by (recovered) sediment at a given site. ots indicates that pelagic caps are thickest (up to $200 \mathrm{~m}$ ) close to the equator, thin to a few tens of meters near $21^{\circ} \mathrm{N}$, and are absent north of $23^{\circ} \mathrm{N}$ latitude (van Waasbergen and Winterer, 1993).

The drilling results and seismic reflection studies indicate that the latitudinal thickness variations follow a very predictable trend throughout the northwestern Pacific. Figure 8 indicates that this thickness relationship can be explained largely by the progressive loss of the Miocene and lower Pliocene toward the north. The middle Miocene through lower Pliocene thin rapidly to the north, disappearing in the interval (approximately $13^{\circ} \mathrm{N}-18^{\circ} \mathrm{N}$ ) between Ita Mai Tai and Horizon guyots. The lower Miocene is still approximately $40 \mathrm{~m}$ thick on Horizon Guyot, but it is absent to the north on Resolution and MIT guyots. The upper Pliocene and Quaternary are thickest between $5^{\circ} \mathrm{N}$ and $15^{\circ} \mathrm{N}$ but are persistent (albeit thinner) to the north.

These thickness variations could be explained either by differing depositional histories (with younger units only deposited nearer the equator) or by erosional processes. Some thickness differences are best explained by their depositional histories. For example, the lower to lower middle Miocene at Site 871 (Limalok Guyot) is significantly thicker than at other sites. Oxygen isotope evidence indicates that surface waters at this site were appreciably warmer during the early middle Miocene than at other sites. This warmer water probably promoted greater productivity. However, seismic reflection evidence suggests that most of the thickness variations are better explained by erosional processes. The second line of evidence comes from comparison of seismic reflection images of the pelagic caps. The southern guyots (Limalok, Lo-En, and Wodejebato) clearly show constructional stratigraphic geometries (as discussed above). A seismic reflection profile of Allison Guyot (van Waasbergen and Winterer, 1993, fig. 2), one of the northern guyots, shows a set of reflectors that clearly are truncated at the margins of the pelagic cap. Drilling on $\mathrm{Al}$ lison Guyot indicates that most of these truncated reflectors are $\mathrm{Pa}$ leogene in age, with only minor (few tens of meters) amounts of upper Cenozoic sediment.

The pelagic cap at Site 873 (Wodejebato) is significantly thinner than predicted by the regression, as is evident in Figure 7. The thickness of lithologic Subunit IA on Wodejebato is not appreciably different from that of Limalok, and it is only $15 \%$ thinner than Subunit IA on nearby Lo-En Guyot. The Miocene section, on the other hand, is significantly thinner and stratigraphically less complete than its correlatives on Limalok, Lo-En, and Ita Mai Tai guyots (Fig. 8). This may be an artifact of the position of Site 873. Examination of seismic

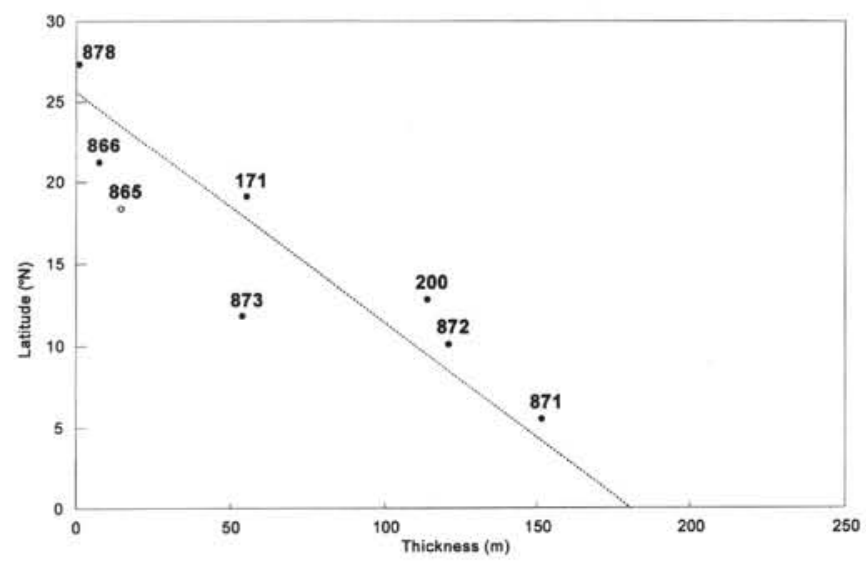

Figure 7. Latitude vs. upper Cenozoic pelagic cap thickness for the seven guyots drilled by DSDP and ODP. The regression line (dotted) follows the formula: thickness $=(-7.0 \times$ latitude $)+180.6$. This relationship predicts that a maximum thickness of approximately $180 \mathrm{~m}$ should be preserved at the equator, with the cap thickness decreasing northward to 0 at approximately $25.7^{\circ} \mathrm{N}$. The data point for Site 865 is plotted (open circle), although it was not used in calculating the regression. 
reflection profiles (Premoli Silva, Haggerty, Rack, et al., 1993, "Site 873 " chapter, fig. 4) suggest that the pelagic cap thickens just to the north of Site 873. The seismic stratigraphic correlations of the section in the immediate vicinity of Site 873 indicate that the basal part of the pelagic cap (correlative to the Miocene) thickens markedly to the north of Site 873. Assuming the seismic stratigraphic correlation is correct, then drilling just to the north of Site 873 should yield a thicker Miocene section that would more closely correspond to the predicted value.

\section{CONCLUSIONS}

The striking similarities of the depositional histories of the Leg 144 pelagic caps suggest that broader patterns of productivity and intermediate-water current activity in the North Pacific gyre are reflected in the construction of the pelagic caps. The following historical scenario is suggested by the evidence from the Leg 144 pelagic caps.

Pelagic cap formation began as the guyots were rafted northward out of the equatorial gyre margin. Wodejebato and Lo-En guyots moved into the central gyre during the late Oligocene, whereas Limalok emerged from the gyre margin during the earliest Miocene. Sediment accumulation through the early Miocene was generally slow and sporadic. Most of the sediment accumulation probably occurred near the center of the summit plateaus or in isolated, sheltered areas. This first pulse of major sediment accumulation occurred during the late early to middle Miocene. This pulse is coincident with a period of higher surface and near-surface temperatures in the equatorial Pacific, as reported by Savin et al. (1985).

Sediment accumulation decreased markedly by the middle middle Miocene, coincident with surface and near-surface water cooling (Savin et al., 1985). A second brief pulse of sediment accumulation occurred during the late Miocene on Lo-En and Ita Mai Tai guyots. This sediment is frequently mixed and contains significant reworking from older Miocene units. It appears likely that much of this material was deposited as dunes of foraminifer ooze, in a manner documented from observations of modern guyots (e.g., Levin and Nittrouer, 1987). Little or no additional sediment accumulation occurred during the remainder of the late Miocene. At least part of this time period probably was characterized by significant erosion at the margins of the pelagic cap, as indicated by exhumation of microfossils from the sediments at the base of the pelagic caps. These exhumed microfossils were transported toward the center of the summit plateau, perhaps by the tidal currents proposed by Lonsdale et al. (1972), and deposited with other reworked and autochthonous sediments during the latest Miocene and earliest Pliocene.

This period of slow sediment accumulation rates, erosion, and reworking during the late Miocene corresponds with the significant reductions in carbonate MAR in the eastern equatorial Pacific. Lyle et al. (1995) and Farrell et al. (1995) document significant decreases in carbonate MAR by $11 \mathrm{Ma}$, followed by the lowest sedimentation rates of the Miocene during the interval from 8 to $10 \mathrm{Ma}$. This carbonate crash of the eastern equatorial Pacific corresponds with the narrowing of the western equatorial Pacific carbonate facies to a narrow band along the equator (van Andel et al., 1975; Lyle et al., 1995). Lyle et al. (1995) and Farrell et al. (1995) attribute the decline of sedimentation rates from 11 to 13 Ma to reductions in surface-water productivity. The carbonate crash (8-11 Ma) was attributed to low productivity and a precipitous rise in the CCD caused by reorganization of the deep circulation resulting from the closure of the deep Panama Gateway. Although the western Pacific guyot summits were well above any reasonable excursions of the $\mathrm{CCD}$, their low sediment accumulation rates suggest lower productivity. In addition, the evidence of significant erosion indicates relatively energetic intermediate-water currents. This increase in current intensity may be linked to the large-scale reorganization of deep- and intermediate-water masses in the equatorial Pacific postulated by Lyle et al. (1995).
During the latest Miocene to earliest Pliocene, winnowed foraminifer ooze deposition (or erosion) generally gave way to finer grained nannofossil foraminifer ooze sedimentation that persisted through the Quaternary. This suggests a lower current regime for the western Pacific intermediate-waters of the gyre center for most of the Pliocene-Pleistocene.

The Marshall Islands guyots appear to be in a constructional phase of their history. To the north, the pelagic caps diminish in size in a predictable manner, so that by about $23^{\circ} \mathrm{N}$ the pelagic caps are no longer present (van Waasbergen and Winterer, 1993). The northern guyots drilled on DSDP Leg 17 and ODP Legs 143 and 144 appear to be in a destructional phase of their development. Younger stratigraphic units are preferentially thin or absent from these guyots. Seismic reflection profiles of northern and southern guyots indicate depositional margins on the southern guyots but a clearly erosional pelagic cap margin on Allison Guyot of the northern group. The evidence for significant erosion of the pelagic caps in the north, coupled with the absence of pelagic caps north of approximately $23^{\circ} \mathrm{N}$, suggests that pelagic caps begin a destructional phase somewhere between $12^{\circ}$ and $18^{\circ} \mathrm{N}$, and are eventually destroyed by erosion. The latitude of destruction corresponds approximately with the northern edge of the North Pacific gyre. This suggests that the higher intermediate-water velocities are a contributing factor to the destruction of the pelagic caps.

Further, the pelagic carbonate caps of the northwestern Pacific guyots are relatively ephemeral features, lasting only a few tens of millions of years. They begin their lives as they drift northward from the equatorial current zone into the gyre center. They are fed by the deposition of the gyre center biota, whose skeletons accumulate because of relatively low intermediate-water current velocities. As they drift through the gyre center and approach the margin, the increased intermediate-water current velocities begin to erode and denude the guyot summit plateaus. Finally, their carbonate is blown off the summit to be dissolved in the depths below. There is some justice, albeit harsh, in this: what the gyre giveth, the gyre taketh away.

\section{ACKNOWLEDGMENTS}

Financial support for this study was provided by JOI-USSAC to the senior author. The authors wish to thank Dr. Mary Anne Holmes, who provided aid during several phases of the study. Work by Jodi Norris is gratefully appreciated. The manuscript was significantly improved thanks to the review of William Sliter and the editorial comments of Jennifer Marin and Eva M. Maddox.

\section{REFERENCES*}

Cande, S.C., and Kent, D.V., 1992. A new geomagnetic polarity time scale for the Late Cretaceous and Cenozoic. J. Geophys. Res., 97:1391713951.

Douglas, R.G., 1973. Planktonic foraminiferal biostratigraphy in the central north Pacific Ocean. In Winterer, E.L., Ewing, J.I., et al., Init. Repts. DSDP, 17: Washington (U.S. Govt. Printing Office), 673-694.

Farrell, J.W., Raffi, I., Janecek, T.R., Murray, D.W., Levitan, M., Dadey, K.A., Emeis, K.-C., Lyle, M., Flores, J.-A., and Hovan, S., 1995. Late Neogene sedimentation patterns in the eastern equatorial Pacific. In Pisias, N.G., Mayer, L.A., Janecek, T.R., Palmer-Julson, A., and van Andel, T.H. (Eds.), Proc. ODP, Sci. Results, 138: College Station, TX (Ocean Drilling Program): 717-756.

Gartner, S., 1977. Calcareous nannofossil biostratigraphy and revised zonation of the Pleistocene. Mar. Micropaleontol., 2:1-25.

\footnotetext{
Abbreviations for names of organizations and publications in ODP reference lists follow the style given in Chemical Abstracts Service Source Index (published by American Chemical Society).
} 
Heezen, B.C., MacGregor, I.D., et al., 1973. Init. Repts. DSDP, 20: Washington (U.S. Govt. Printing Office).

Hekel, H., 1973. Nannofossil biostratigraphy, Leg 20, Deep Sea Drilling Project. In Heezen, B.C., MacGregor, I.D., et al., Init. Repts. DSDP, 20: Washington (U.S. Govt. Printing Office), 221-247.

Krasheninnikov, V.A., and Hoskins, R.H., 1973. Late Cretaceous, Paleogene and Neogene planktonic foraminifera. In Heezen, B.C., MacGregor, I.D. et al., Init. Repts. DSDP, 20: Washington (U.S. Govt. Printing Office), 105-203.

Levin, L.A., and Nittrouer, C.A., 1987. Textural characteristics of sediments on deep seamounts in the Eastern Pacific Ocean between $10^{\circ} \mathrm{N}$ and $30^{\circ} \mathrm{N}$. In Keating, B.H., Fryer, P., Batiza, R., and Boehlert, G.W. (Eds.), Seamounts, Islands, and Atolls. Geophys. Monogr., Am. Geophys. Union. 43:187-203.

Lincoln, J.M., Pringle, M.S., and Premoli-Silva, I., 1993. Early and Late Cretaceous volcanism and reef-building in the Marshall Islands. In Pringle, M.S., Sager, W.W., Sliter, W.V., and Stein, S. (Eds.), The Mesozoic Pacific: Geology, Tectonics, and Volcanism. Geophys. Monogr., Am. Geophys. Union, 77:279-305.

Lonsdale, P., Normark, W.R., and Newman, W.A., 1972. Sedimentation and erosion on Horizon Guyot. Geol. Soc. Am. Bull., 83:289-315.

Lyle, M., Dadey, K., and Farrell, J., 1995. The late Miocene (11-8 Ma) eastern Pacific carbonate crash: evidence for reorganization of deep-water circulation by the closure of the Panama Gateway. In Pisias, N.G., Mayer, L.A., Janecek, T.R., Palmer-Julson, A., and van Andel, T.H. (Eds.), Proc. ODP, Sci. Results, 138: College Station, TX (Ocean Drilling Program), 821-838.

Premoli Silva, I., Haggerty, J., Rack, F., et al., 1993. Proc. ODP, Init. Repts., 144: College Station, TX (Ocean Drilling Program).
Rio, D., Fornaciari, E., and Raffi, I., 1990. Late Oligocene through early Pleistocene calcareous nannofossils from western equatorial Indian Ocean (Leg 115). In Duncan, R.A., Backman, J., Peterson, L.C., et al., Proc. ODP, Sci. Results, 115: College Station, TX (Ocean Drilling Program), $175-235$.

Roth, P.H., 1973. Calcareous nannofossils-Leg 17, Deep Sea Drilling Project. In Winterer, E.L., Ewing, J.I., et al., Init. Repts. DSDP, 17: Washington (U.S. Govt. Printing Office), 695-795.

Sager, W.W., Winterer, E.L., Firth, J.V., et al., 1993. Proc. ODP, Init. Repts., 143: College Station, TX (Ocean Drilling Program).

Savin. S.M., Abel, L., Barrera, E., Hodell, D.A., Keller, G., Kennett, J.P., Killingley, J.S., Murphy, M., and Vincent, E., 1985. The evolution of Miocene surface and near-surface marine temperatures: oxygen isotopic evidence. In Kennett, J.P. (Ed.), The Miocene Ocean: Paleoceanography and Biogeography. Mem.-Geol. Soc. Am., 163:49-82.

van Andel, T.H., Heath, G.R., and Moore, T.C., Jr., 1975. Cenozoic history and paleoceanography of the central equatorial Pacific Ocean: a regional synthesis of Deep Sea Drilling Project data. Mem.-Geol. Soc. Am., 143.

van Waasbergen, R.J., and Winterer, E.L., 1993. Summit geomorphology of Western Pacific guyots. In Pringle, M.S., Sager, W.W., Sliter, W.V., and Stein, S. (Eds.), The Mesozoic Pacific: Geology, Tectonics, and Volcanism. Geophys. Monogr., Am. Geophys. Union, 77:335-366.

Winterer, E.L., Ewing, J.I., et al., 1973. Init. Repts. DSDP, 17: Washington (U.S. Govt. Printing Office).

Date of initial receipt: 3 August 1994

Date of acceptance: 4 January 1995

Ms 144SR-066 